\title{
Turning the Page
}





\section{Turning the Page}

\section{Storytelling as Activism in Queer Film and Media}

DAVID R. COON

\section{rid}

\section{Rutgers University Press}


Library of Congress Cataloging-in-Publication Data

Names: Coon, David R., 1974- author.

Title: Turning the page : storytelling as activism in queer film and media / David R. Coon.

Description: New Brunswick : Rutgers University Press, 2018. | Includes bibliographical references and index.

Identifiers: LCCN 2017055199 | ISBN 9780813593708 (cloth : alk. paper) | ISBN

9780813593692 (pbk. : alk. paper)

Subjects: LCSH: Sexual minorities in mass media. | Gay liberation movement-United States.

Classification: LCC P96.S58 C66 2018 | DDC 302.23086/64-dc23

LC record available at https://lccn.loc.gov/2017055199

A British Cataloging-in-Publication record for this book is available from the British Library.

Copyright (C) 2018 by David R. Coon

All rights reserved

No part of this book may be reproduced or utilized in any form or by any means, electronic or mechanical, or by any information storage and retrieval system, without written permission from the publisher. Please contact Rutgers University Press, Io 6 Somerset Street, New Brunswick, NJ 0890 . The only exception to this prohibition is "fair use" as defined by U.S. copyright law.

(o)

The paper used in this publication meets the requirements of the American National Standard for Information Sciences-Permanence of Paper for Printed Library Materials, ANSI Z39.48-I992.

www.rutgersuniversitypress.org

Manufactured in the United States of America 
For all the storytellers and activists making the world a better place 
